ISSN 2077-1827. Гуманізація навчально-виховного процесу. 2019, №. 6 (98)

РОЗДІЛ. ВИЩА ШКОЛА

УДК 378.147:37.011.3-051]:004

\title{
САЯПІНА Світлана
}

доктор педагогічних наук, доцент, професор кафедри педагогіки вищої школи ДВНЗ «Донбаський державний педагогічний університет»

вул. генерала Батюка, 19, м. Слов’янськ, 84116, Україна

E-mail:svetlana.sayapina65@gmail.com

\section{ДРОЗДОВА Ірина}

здобувач магістерського рівня освіти ДВНЗ «Донбаський державний педагогічний університет»

вул. генерала Батюка, 19, м. Слов’янськ, 84116, Україна

E-mail:super-ira09@ukr.net

\section{ФОРМУВАННЯ ІНФОРМАЦІЙНО-КОМУНІКАЦІЙНӦ̈ КОМПЕТЕНТНОСТІ МАЙБУТНІХ УЧИТЕЛІВ}

Анотація. У статті розглянуто проблеми, пов'язані зі структуруванням інформаційно-комунікаційної компетентності студентів гуманітарних спеціальностей педагогічного профілю та процесом їі формування. Автори доходять висновку, що успішне формування інформаційно-комунікаційної компетентності можливе за умови цілеспрямованого та системного підходів у рамках освітнього процесу закладу вищої освіти. Доведено, що важливим чинником розвитку ІК-компетентності студентів гуманітарних спеціальностей педагогічного профілю може стати дистанційна підтримка курсу «ІКТ в освіті». Систематичне рішення освітніх завдань за допомогою інтернет-технологій природним чином сприяє розвитку ІК-компетентності майбутніх учителів. Акцентовано увагу на тому, що необхідною умовою для розробки педагогічної моделі процесу формування ІК-компетентності $\epsilon$ визначення змісту і структури ІК-компетентності майбутнього вчителя.

Структуризація ІК-компетентності дозволяє вибудовувати міжпредметні зв'язки й діагностувати ефективність процесу формування IКкомпетентності. Визначено набір взаємозв'язаних між собою компетенцій, що становлять ІК-компетентність студентів гуманітарних спеціальностей педагогічного профілю (технологічні компетенції (володіння різноманітним комп'ютерним обладнанням i програмним забезпеченням, мережевими технологіями, технологіями мультимедіа, презентаційними технологіями, технологіями створення портфоліо тощо); інформаційні компетенції (навички роботи з інформацією: ідентифікація, пошук, управління, інтеграція, оцінка, створення інформації, передача тощо); прикладні професійні компетенції (здатність використовувати ІКТ для проєктування й реалізації особистісно зорієнтованого процесу навчання, здійснення оцінки навчальних досягнень учнів, конструювання навчальних занять, цифрових освітніх ресурсів тощо)).

(C) Саяпіна С., Дроздова I., 2019 
ISSN 2077-1827. Гуманізація навчально-виховного процесу. 2019, №. 6 (98)

РОЗДІЛ. ВИЩА ШКОЛА

Ключові слова: інформаційно-комунікаційні технологї, інформаційно-комунікаційна компетентність, структура інформаційнокомунікаційної компетентності, майбутній учитель, гуманітарний профіль.

Постановка проблеми в загальному вигляді та іï зв'язок 3 важливими науковими чи практичними завданнями. Освіта як система, основною функцією якої є формування та розвиток професійно компетентної особистості, зазнає постійних змін різного масштабу: від іiі глобальної модернізації, корінних змін законодавчої бази до впровадження окремих інновацій у закладах освіти, а отже, перебуває в стані реформування.

Ключову роль у підготовці молодого покоління до життя в мінливому інформаційному суспільстві відіграє володіння сучасною людиною інформаційними та комунікаційними технологіями (далі IКТ). Стрімко зростаючий обсяг знань про навколишній світ, ІКТ, що постійно вдосконалюються, змінюють способи отримання знань, роль учителя та методи його роботи, висувають усе більш високі вимоги до його інформаційно-комунікаційної компетентності (далі ІК-компетентності).

Виявлення педагогічних умов ефективного формування ІКкомпетентності, а також розробка та обгрунтування педагогічної моделі формування IК-компетентності в студентів гуманітарних спеціальностей педагогічного профілю - важливі дослідницькі завдання для сучасної педагогічної науки.

Аналіз останніх досліджень і публікацій, у яких започатковано розв'язання цієї проблеми $\mathbf{i}$ на які спирається автор, виділення невирішених раніше частин загальної проблеми, котрим присвячується означена стаття. Проблема формування інформаційно-комунікаційної компетентності (далі IКК) не нова й досить широко досліджена. Певні іiі напрями розглянуто В. Безпалько (інтегральна характеристика особистості, що включає мотивацію до засвоєння відповідних знань, здібність до вирішення завдань у навчальній і професійній діяльності за допомогою комп'ютерної техніки та володіння прийомами комп'ютерного мислення); О. Шиловою та М. Лебедєвою (здатність індивіда вирішувати навчальні, життєві, професійні завдання 3 використанням інформаційно-комунікаційних технологій); А. Слізаровим (сукупність знань, умінь і досвіду діяльності, причому саме наявність такого досвіду $\epsilon$ визначальною відносно виконання професійних функцій); Л. Горбуновою і А. Семибратовим (готовність і здатність педагога самостійно й відповідально використовувати ці технології у своїй професійній діяльності); Л. Гавриловою, Я. Топольник (формування IКК у системі інформаційно-комунікаційної підтримки наукових досліджень майбутніх магістрів); В. Величко (сучасні підходи до використання IКТ у процесі підготовки майбутніх учителів математики, фізики та інформатики) та ін.

Для визначення рівня професіоналізму педагога у сфері використання IКT застосовано термін «ІК-компетентність» (або «ІКТ-компетентність»). Багато авторів розглядають ІК-компетентність як готовність і здатність педагога самостійно та відповідально використовувати інформаційно-комунікаційні 
технології у своїй професійній діяльності (С. Баранова, Л. Біденко, О. Валовик, О. Семеног, С. Скворцова, С. Томіліна, Л. Чернікова та ін.).

Формулювання цілей статті. Мета статті полягає в розкритті теоретичних підходів до формування IК-компетентності майбутніх учителів, характеристиці критерії відбору змісту та структурування навчального міждисциплінарного курсу «IКТ в освіті» для студентів гуманітарних спеціальностей педагогічного профілю.

Виклад основного матеріалу дослідження 3 повним обгрунтуванням отриманих наукових результатів. Розгляд процесу формування IKкомпетентності майбутнього вчителя виявляє кілька проблем. По-перше, автори по-різному бачать кількість і перелік компетенцій, що становлять структуру ІК-компетентності. По-друге, недостатньо досліджено питання наступності при формуванні ІК-компетентності на рівні загальної й професійної освіти. По-третє, не визначено специфіку ІК-компетентності студентів і вчителів гуманітарних спеціальностей, через що ускладнено визначення педагогічних умов ефективного формування в них IКкомпетентності $[1 ; 2 ; 4 ; 7]$.

Традиційно ІК-компетентність учасників освітнього процесу ототожнюється із системою знань, умінь і навичок, що формується в процесі вивчення освітньої галузі «інформатика». А розв'язання проблеми формування ІК-компетентності майбутнього вчителя пропонується вирішувати через додавання до змісту основної традиційної «інформатичної» освіти одержуваних у ЗВО двох нових спеціалізованих дидактичних одиниць: IKT в освіті та IКТ у дисциплінах предметної підготовки вчителя [9; 10].

Запропонована в рамках експериментального проєкту «Інформатизація системи освіти» (ICO) концепція інформаційно-комунікаційної компетентності випускника школи визначає IКТ-грамотність, яка формується в процесі вивчення інформатики як базису ІК-компетентності школяра. Своєю чергою, ІК-компетентність розглядають як ключову надпредметну компетентність, яка формується при вивченні всіх предметів у старшій школі й не повинна обмежуватися технологічними навичками. При цьому під IКкомпетентністю розуміється впевнене володіння всіма складовими навичками ІКТ-грамотності для вирішення різноманітних завдань у навчальній та іншій діяльності. Автори цього підходу вважають, що структуру ІК-компетентності випускника середньої школи становлять універсальні пізнавальні навички (компетенції), пов'язані з обробкою інформації і здійснювані за допомогою IКТ (ідентифікація, пошук, управління, інтеграція, оцінка, створення, передача) $[2 ; 4 ; 5]$.

Уважаємо, що ця концепція формування ІК-компетентності може бути екстрапольована i на систему підготовки студентів гуманітарних спеціальностей педагогічного профілю. При цьому очевидно, що ІКкомпетентність майбутнього вчителя - більш складне явище. Майбутні вчителі повинні вміти використовувати засоби IКТ для вирішення навчальних i дослідницьких завдань, а в перспективі - для ефективного навчання 
ISSN 2077-1827. Гуманізація навчально-виховного процесу. 2019, №. 6 (98)

РОЗДІЛ. ВИЩА ШКОЛА

школярів свого предмета та формування надпредметних ІК-компетентностей, у широкому сенсі - інформаційної культури учня.

Концепція ІК-компетентності як ключової, надпредметної компетентності була покладена нами в основу конструювання процесу теоретичної й практичної підготовки студентів гуманітарних спеціальностей педагогічного профілю до використання IKT у професійній діяльності. Основною метою такої підготовки є не саме використання IКТ, а підвищення якості викладання гуманітарних дисциплін у загальноосвітній школі.

У ході дослідження дійшли висновку, що процес формування ІКкомпетентності студентів-гуманітаріїв повинен здійснюватися на основі таких принципів: педагогічної доцільності, системності, наступності, гуманітаризації.

Педагогічна доцільність передбачає, що педагогічна наука визначає, які технології і яким чином слід використовувати вчителю для вирішення його професійних завдань, пов'язаних із навчанням, розвитком і вихованням учнів.

Принцип наступності визначає процес формування ІК-компетентності майбутніх учителів як доцільно організований, який базується на єдиній концепції ІК-компетентності для всіх ступенів вітчизняної системи освіти, що спирається на ІК-компетентність, отриману випускником школи, i орієнтується на цілі та завдання, що стоять перед майбутнім молодим фахівцем.

Принцип системності означає, що процес формування IKкомпетентності майбутніх учителів гуманітарних предметів цілеспрямовано реалізується на основі міжпредметних зв'язків між навчальними дисциплінами в рамках навчального плану (інформатика та математика, педагогіка, IКТ в освіті, методика викладання тощо). Курсу «ІКТ в освіті» відведено роль інтегрувального, що систематизує й узагальнює знання про застосування IКТ у професійній діяльності майбутнього вчителя.

Принцип гуманітаризації передбачає, що при формуванні IKкомпетентності враховується специфіка гуманітарних знань. IКТ розглядається як засіб для вирішення завдань гуманітарної освіти (формування цінностей, розвиток комунікативних компетенцій, емоцій i естетичних почуттів).

Провівши аналіз теоретичних підходів до формування ІКкомпетентності майбутніх учителів, сформульовано критерії відбору змісту та структурування навчального міждисциплінарного курсу «IКТ в освіті» для студентів гуманітарних спеціальностей педагогічного профілю. Для побудови курсу необхідно враховувати: вимоги державних освітніх стандартів; сучасний стан гуманітарних і педагогічних наук, а також «інформатичної» освіти; сучасний стан i тенденції розвитку IКТ; світовий досвід інформатизації вищої освіти; вимоги навчальних планів конкретного ЗВО; наявність єдиної концепції ІК-компетентності всіх учасників освітнього процесу.

Проведене дослідження дозволяє стверджувати, що необхідною умовою для розробки педагогічної моделі процесу формування IK- 
ISSN 2077-1827. Гуманізація навчально-виховного процесу. 2019, №. 6 (98)

РОЗДІЛ. ВИЩА ШКОЛА

компетентності $€$ визначення змісту i структури ІК-компетентності майбутнього вчителя. Структуризація IK-компетентності дозволяє вибудовувати міжпредметні зв'язки й діагностувати ефективність процесу формування ІК-компетентності. Ми визначили набір взаємозв'язаних між собою компетенцій, що становлять ІК-компетентність студентів гуманітарних спеціальностей педагогічного профілю, розділивши їх на кілька груп:

- технологічні компетенції (володіння різноманітним комп'ютерним обладнанням i програмним забезпеченням, мережевими технологіями, технологіями мультимедіа, презентаційними технологіями, технологіями створення портфоліо тощо);

- інформаційні компетенції (навички роботи 3 інформацією: ідентифікація, пошук, управління, інтеграція, оцінка, створення інформації, передача тощо);

- прикладні професійні компетенції (здатність використовувати IКТ для проєктування й реалізації особистісно зорієнтованого процесу навчання, здійснення оцінки навчальних досягнень учнів, конструювання навчальних занять, конструювання цифрових освітніх ресурсів тощо).

Наш досвід свідчить, що важливим чинником розвитку ІКкомпетентності студентів гуманітарних спеціальностей педагогічного профілю може стати дистанційна підтримка курсу «IКТ в освіті». Систематичне рішення освітніх завдань за допомогою інтернет-технологій природним чином сприяє розвитку ІК-компетентності майбутніх учителів.

Висновки 3 цього дослідження і перспективи подалыших розвідок у цьому напрямі. Отже, відзначимо, що ІК-компетентність майбутнього вчителя ми розглядаємо в контексті загальної професійної компетентності, усі компоненти якої взаємопов'язані між собою й комплексно проявляються в процесі професійної діяльності. ІК-компетентність $€$ своєрідним інтегратором, що впливає на якісний зміст усіх компонентів професійної компетентності майбутнього вчителя гуманітарних предметів, реалізує зв'язок між дидактичними, психолого-педагогічними, предметнометодичними основами педагогічних технологій i функційними можливостями сучасних засобів IКТ.

\section{СПИСОК ВИКОРИСТАНОЇ ЛІТЕРАТУРИ}

1. Баранова С. Особливості формування професійної компетентності вчителя. Сучасна школа України. Шкільний світ. 2009. № 3. С. 16-18.

2. Біденко Л. В. Інформаційно-комунікаційна компетентність як складова професійної компетентності майбутнього вчителя російської мови. Викладання мов у вищих навчальних закладах освіти на сучасному етапі. Міжпредметні зв'язки. Наукові дослідження. Досвід. Пошуки. 2013. Вип. 22. C. 33-41.

3. Валовик О.А. Мотивація педагога як умова зростання професійної компетентності. Управління школою. 2009. № 10. С. 10-16.

4. Величко В. С. Сучасні підходи до використання ІКТ у процесі підготовки майбутніх учителів математики, фізики та інформатики. Педагогіка вищої 
ISSN 2077-1827. Гуманізація навчально-виховного процесу. 2019, №. 6 (98)

РОЗДІЛ. ВИЩА ШКОЛА

та середньої школи. Кривий Ріг: ВЦ КДПУ; Айс Принт. Вип. 3 (49), 2016. С. 17-26.

5. Гаврілова Л. Г., Топольник Я. В. Цифрова культура, цифрова грамотність, цифрова компетентність як сучасні освітні феномени. Інформаційні технологї $i$ засоби навчання: електронне наукове фахове видання, 2017. т. 61. № 5. С. 1-14. [Електронний ресурс]. Доступно : https://journal.iitta.gov.ua/index.php/itlt/issue/view/90.

6. Дейнеко С. В. Педагогічна компетентність учителя як умова та засіб гуманізації освітнього середовища. Управління шкколою. 2007. № 4. С. 2-7.

7. Семеног О. М. Сучасні інформаційні технології у професійній філологічній освіті: проблеми, пошуки, перспективи. Сучасні інформаційні технології та інноваційні методики навчання у підготовці фахівців: методологія, досвід, проблеми: збірник наукових праць. Київ; Вінниця: ДОВ Вінниця, 2004. Вип. 5. С. 631-638.

8. Скворцова С. Професійна компетентність: зміст поняття та класифікація. Наукові записки ТНПУ ім. В. Гнатюка. Сер. Педагогіка. Тернопіль, 2009. № 5. C. 27-33.

9. Томіліна С. С. Професійна компетентність сучасного педагога. Педагогічні науки : зб. наук. пр. Херсон, 2007. Вип. 45. С. 368-371.

10. Чернікова Л. А. Сутність ІКТ-компетентності педагога. ПостМетодика. 2009. №4 (88). C. 46-51.

Стаття надійшла до редакції 05.11.2019.

\section{САЯПИНА Светлана}

доктор педагогических наук, доцент, профессор кафедры педагогики высшей школы

ГВУЗ «Донбасский государственный педагогический университет»

ул. генерала Батюка, 19, г. Славянск, 84116, Украина

E-mail: svetlana.sayapina65@gmail.com

\section{ДРОЗДОВА Ирина}

соискатель магистерского уровня образования ДВНЗ «Донбасский государственный педагогический университет»

ул. генерала Батюка, 19, г. Славянск, 84116, Украина

E-mail: super-ira09@ukr.net

ФОРМИРОВАНИЕ

КОММУНИКАЦИОННОЙ УЧИТЕЛЕЙ

Резюме. В статье рассматриваются проблемы, связанные со структурированием информационно-коммуникационной компетентности студентов гуманитарных специальностей педагогического профиля и процессом ее формирования. Авторы приходят к выводу, что успешное формирование информационно-коммуникационной компетентности возможно при целенаправленном и системном подходе в рамках образовательного процесса учреждения высшего образования. Доказано, что важным фактором развития ИК-компетентности студентов гуманитарных 
ISSN 2077-1827. Гуманізація навчально-виховного процесу. 2019, №. 6 (98)

РОЗДІЛ. ВИЩА ШКОЛА

специальностей педагогического профиля может стать полная поддержка курса «ИКТ в образовании». Систематическое решение образовательных задач с помощью интернет-технологий естественным образом способствует развитию ИК-компетентности будущих учителей. Акцентировано внимание на том, что необходимым условием для разработки педагогической модели процесса формирования ИК-компетентности является определение содержания и структуры ИК-компетентности будущего учителя. Структуризация ИК-компетентности позволяет выстраивать межпредметные связи и диагностировать эффективность процесса формирования ИКкомпетентности. Определен набор взаимосвязанных между собой компетенций, составляющих ИК-компетентность студентов гуманитарных специальностей педагогического профиля (технологические компетенции (владение разнообразным компьютерным оборудованием и программным обеспечением, сетевыми технологиями, технологиями мультимедиа, презентационными технологиями, технологиями создания портфолио и т.д.), информационные компетенции (навыки работы с информацией: идентификация, поиск, управление, интеграция, оценка, создание информации, передача и т.д.); прикладные профессиональные компетенции (способность использовать ИКТ для проектирования и реализации личностно ориентированного образовательного процесса, осуществления оценки учебных достижений учащихся, конструирование учебных занятий, конструирование цифровых образовательных ресурсов и т.д.)).

Ключевые слова: информационно-коммуникационные технологии, информационно-коммуникационная компетентность, структура информационно-коммуникационной компетентности, будущий учитель, гуманитарный профиль.

\section{SAIAPINA Svitlana}

Doctor of Pedagogical Sciences, Associate Professor, Professor of the Department of Pedagogy of Higher School of the SHEI "Donbas State Pedagogical University"

19, Henerala Batiuka Str., Sloviansk, 84116, Ukraine

E-mail: svetlana.sayapina65@gmail.com

\section{DROZDOVA Iryna}

Applicant of Master's Degree of Education of the SHEI "Donbas State Pedagogical University"

19, Henerala Batiuka Str., Sloviansk, 84116, Ukraine

E-mail: super-ira09@ukr.net

\section{FORMING INFORMATION AND COMMUNICATION COMPETENCE OF FUTURE TEACHERS}

Summary. The article deals with the problems related to the structuring of the information and communication competence (IC-competence) of students of humanitarian specialities of the pedagogical profile and the process of its 
formation. The authors conclude that the successful formation of the information and communication competence is possible with a purposeful and systematic approach within the educational process of an institution of higher education. The set of interrelated competences constituting the IC-competence of students of humanitarian specialties of the pedagogical profile is defined. They are technological, informational, applied professional.

Keywords: information and communication technologies, information and communication competence, structure of information and communication competence, future teacher, humanitarian profile.

Abstract. Introduction. The modern man's possession of information and communication technologies (hereinafter ICT) plays a key role in preparing the younger generation for life in a changing information society. The rapidly increasing amount of knowledge about the world, constantly changing ICT, the role of the teacher and the methods of his/her work is making great demands of his/her information and communication competence (hereafter IC-competence).

Analysis of publications. To determine the level of professionalism of an educator in the field of using ICT, the term "IC-competence" (or "ICT- competence") is used. Many authors consider the IC-competence as an educator's willingness and ability to use information and communication technologies independently and responsibly in his/her professional activities (S. Baranova, L. Bidenko, O. Valovyk, S. Skvortsova, O. Semenoh, S. Tomilina, L. Chernikova, and others).

Purpose. The purpose of the article is to expose theoretical approaches to the formation of the IC-competence of future teachers, to characterize the criteria for content selection and to the structure of the educational interdisciplinary course "ICT in Education" for students of humanitarian specialities of the pedagogical profile.

Results. The conducted research allows confirming that a necessary prerequisite for the development of a pedagogical model of the process of formation of the IC-competence is to determine the content and structure of the IC-competence of the future teacher. The structuring of the IC-competences allows building interdisciplinary links and diagnosing the effectiveness of the IC-competence formation process. It has identified the set of interrelated competences that make up the IC-competency of students in the humanitarian specialities of the pedagogical profile, dividing them into several groups: technological competences (possessing different computer hardware and software, networking technologies, multimedia technologies, presentation technologies, portfolio creation technologies, etc.); informational competences (skills of working with information: identification, search, management, integration, evaluation, information creation, transfer, etc.); applied professional competences (the ability to use ICTs for designing and implementing a personality-oriented learning process, to evaluate students' learning achievements, to design training classes, to design digital educational resources, etc.).

Our experience shows that distance support of the course "ICT in Education" can be an important factor in the development of the IC-competence of students of humanitarian specialities of the pedagogical profile. The systematic solution of educational tasks with the help of Internet technologies naturally contributes to the development of the IC-competence of future teachers. 
Conclusion. So, it should be noted that the IC-competence of the future teacher is considered in the context of general professional competence, all components of which are interconnected and complexly manifested in the process of professional activity. The IC-competence is a kind of integrator that influences the qualitative content of all the components of the professional competence of the future teacher of the humanities, realizes the connection between didactic, psychological and pedagogical, subject-methodological bases of the pedagogical technologies and functional capabilities of modern means of the ICT.

\section{REFERENCES}

1. Baranova, S. (2009). Osoblyvosti formuvannia profesiinoi kompetentnosti vchytelia [Peculiarities of forming the teacher's professional competence]. Suchasna shkola Ukrainy. Shkilnyi svit-Modern School of Ukraine. School World, 3, 16-18 [in Ukrainian].

2. Bidenko, L. V. (2013). Informatsiino-komunikatsiina kompetentnist yak skladova profesiinoi kompetentnosti maibutnoho vchytelia rosiiskoi movy [Information and communication competence as a component of professional competence of future Russian language teacher]. Vykladannia mov $u$ vyshchykh navchalnykh zakladakh osvity na suchasnomu etapi. Mizhpredmetni zviazky. Naukovi doslidzhennia. Dosvid. Poshuky - Teaching Languages at Higher Educational Institutions at the Present Stage. Interdisciplinary Ties. Scientific Investigations. Experience. Searches, 22, 33-41 [in Ukrainian].

3. Valovyk, O. A. (2009). Motyvatsiia pedahoha yak umova zrostannia profesiinoi kompetentnosti [Motivation of the teacher as a condition of growth of professional competence]. Upravlinnia shkoloiu-Management of School, 10, 10-16 [in Ukrainian].

4. Velychko, V. Ie. (2016). Suchasni pidkhody do vykorystannia IKT u protsesi pidhotovky maibutnikh uchyteliv matematyky, fizyky ta informatyky [Modern approaches of using ICTs in the process of training future teachers of Maths, Physics, Informatics]. Pedahohika vyshchoi ta serednoi shkoly Pedagogy of Higher and Secondary School, 3 (49), 17-26. Kryvyi Rih: VTs KDPU; Ais Prynt [in Ukrainian].

5. Havrilova, L. H., Topolnyk, Ya. V. (2017). Tsyfrova kultura, tsyfrova hramotnist, tsyfrova kompetentnist yak suchasni osvitni fenomeny [Digital culture, digital literacy, digital competence as modern educational phenomena]. Informatsiini tekhnolohii $i$ zasoby navchannia: elektronne naukove fakhove vydannia - Information Technologies and Learning Tools: Electronic Scientific Professional Journal, vol. 61, 5. 1-14. [Online]. Available at: https://journal.iitta.gov.ua/index.php/itlt/issue/view/90. [in Ukrainian].

6. Deineko, S. V. (2007). Pedahohichna kompetentnist uchytelia yak umova ta zasib humanizatsii osvitnoho seredovyshcha [Pedagogical competence of teacher as a condition and means of humanization of educational environment]. Upravlinnia shkoloiu - Management of School, 4, 2-7 [in Ukrainian]. 
ISSN 2077-1827. Гуманізація навчально-виховного процесу. 2019, №. 6 (98)

РОЗДІЛ. ВИЩА ШКОЛА

7. Semenoh, O. M. (2004). Suchasni informatsiini tekhnolohii u profesiinii filolohichnii osviti: problemy, poshuky, perspektyvy [Modern information technologies at professional philological education: problems, searches, prospects]. Suchasni informatsiini tekhnolohii ta innovatsiini metodyky navchannia u pidhotovtsi fakhivtsiv: metodolohiia, dosvid, problemy: zbirnyk naukovykh prats - Modern Information Technologies and Innovative Learning Techniques at Training Specialists: Collection of Scientific Works, 5, 631-638. Kyiv; Vinnytsia: DOV Vinnytsia [in Ukrainian].

8. Skvortsova, S. (2009). Profesiina kompetentnist: zmist poniattia ta klasyfikatsiia [Professional competence: the content of concept and classification]. Naukovi zapysky TNPU im. V. Hnatiuka. Ser. PedahohikaScientific Proceedings of TNPU named after V. Hnatiuk. Series: Pedagogy, 5, 27-33. Ternopil [in Ukrainian].

9. Tomilina, S. S. (2007). Profesiina kompetentnist suchasnoho pedahoha [Professional competence of modern educator]. Pedahohichni nauky: $z b$. nauk. pr. - Pedagogical Sciences: Collection of Scientific Works, 45, 368371. Kherson [in Ukrainian].

10. Chernikova, L. A. (2009). Sutnist IKT-kompetentnosti pedahoha [Essence of ICT-competence of an educator]. PostMetodyka - PostMethods, 4 (88), 4651 [in Ukrainian].

(англійською переклала В. Слабоуз - кандидат філологічних наук, доцент, доцент кафедри іноземних мов ДДПУ)

\section{УДК 372.881.111.1}

\section{ГОРІДЬКО Наталія}

канд. тех наук, доцент, доцент кафедри іноземних мов, Національний транспортний університет

вул. М. Омеляновича-Павленка, 1, м. Київ, Україна, 01010

E-mail: natalia.horidko@ukr.net

\section{АСТАНІНА Наталя}

доцент, завідувач кафедри іноземних мов, Національний транспортний університет

вул. М. Омеляновича-Павленка, 1, м. Київ, Україна, 01010

E-mail: natanina922@,gmail.com

\section{ШЛЯХИ \\ ПІДВИЩЕННЯ ІНШОМОВНОї ПІДГОТОВКИ СПЕЦАЛЬНОСТЕЙ \\ ЯКОСТІ
СТУДЕНТІВ \\ ПРОФЕСІЙНӦ̈ ІНЖЕНЕРНИХ}

Анотація. У статті висвітлені шляхи підвищення рівня якості навчання іноземних мов у немовному закладі вищої освіти на засадах інноваційних підходів та технологій. Охарактеризувавши суть інноваційних технологій у навчальному процесі, визначені переваги їх застосування при вивченні іноземних мов. Інтерактивні технології сприяють поглибленню та (C) Горідько Н., Астаніна Н., 2019 